\title{
Learning from Safeguarding Adult Reviews on Self-Neglect: Addressing the Challenge of Change
}

\begin{tabular}{|r|l|}
\hline Journal: & The Journal of Adult Protection \\
\hline Manuscript ID & JAP-01-2018-0001.R1 \\
\hline Manuscript Type: & Research Paper \\
\hline Keywords: & $\begin{array}{l}\text { change, action plans, self-neglect, safeguarding adult reviews, Care Act } \\
\text { 2014, England }\end{array}$ \\
\hline \multicolumn{2}{|l}{} \\
\hline
\end{tabular}

\section{SCHOLARONE ${ }^{\text {m }}$ \\ Manuscripts}




\section{Learning from Safeguarding Adult Reviews on Self-Neglect: Addressing the Challenge of Change}

\section{Introduction}

Cases of adults who self-neglect continue to challenge practitioners, the agencies for which they work, and Safeguarding Adults Boards (SABs). One thematic review of safeguarding adult reviews (SARs) ( $n=27)$, commissioned and completed by SABs in the London region between April 2015 and April 2017, found that 33\% centrally involved self-neglect (Braye and Preston-Shoot, 2017). A second thematic review (Preston-Shoot, 2017a), of serious case reviews (SCRs) and SARs commissioned and completed by SABs in the South West region between January 2013 and July 2017 ( $n=37)$, found that $32 \%$ centrally involved self-neglect. Both thematic reviews also contained reviews where self-neglect combined with other forms of abuse and neglect, adding further complexity.

Previous analyses of reviews involving self-neglect have identified the complexities, dilemmas and challenges for practitioners, agencies, and multi-agency partnerships, and highlighted the components of effective adult safeguarding (Braye and Preston-Shoot, 2015a; 2015b; Preston-Shoot, 2016; 2017b). However, the on-going prominence of self-neglect cases amongst the SARs commissioned by $S A B s$, and the similarities within their findings, invites further scrutiny into the facilitators and barriers for effective practice across adult safeguarding systems - organisations, inter-agency working, and the financial, policy and legal context within which SABs and their partners function. It also invites inquiry into how SABs and their partner agencies approach the challenge of change, of translating and then embedding review findings and recommendations into effective arrangements for direct practice with adults who self-neglect.

This article, then, has two objectives. The first is to update the database on SARs involving selfneglect and to refresh the learning available from them. The second is to review how SABs are approaching the challenge of change and to develop strategies for impactful use of SARs.

\section{Methodology}

All SAB websites in England were accessed in Autumn 2017 and published SARs read for references to self-neglect. Some unpublished SARs were retrieved from one thematic review (Braye and Preston-Shoot, 2017) and through personal contacts with SAB Independent Chairs and Business Managers. The same analytic approach is used here as previously (Braye et al., 2015a; 2015b), with case numbering continuing the database sequence (Preston-Shoot, 2017). Thus, initial analysis explored the key characteristics of each case and of each review, followed by the frequency of different types of recommendations and the themes within them. Subsequently, a four-domain approach was used to organise the themes extracted from reading review findings, with a focus on identified good practice as well as learning for change.

Proposed regional and/or national repositories may make it easier for SABs and their partner agencies to learn from experience elsewhere. Currently, however, learning remains largely localised and it is time consuming and sometimes challenging to track down SARs.

\section{Layer one: case characteristics}


In the complete sample ( $n=134)$, where gender is known and noting in some cases the presence of more than one person, men outnumber women (74/58), with one person reported as transgender. The largest age group remains people aged over 76 (24\%), followed by those aged $40-59$ (23\%) and those aged 60-75 (19\%). Age is withheld in just over a quarter of cases. Ethnicity is rarely recorded, as found also in other thematic appraisals of SARs (Braye and Preston-Shoot, 2017; Preston-Shoot, 2017a). Within this sub-sample and across the sample as a whole, refusal of services ( $n=23$ and 81 ) and lack of self-care ( $n=24$ and 78 ) are more prominent, and often combined in cases, than lack of care of one's environment ( $n=2$ and 34). All three components of self-neglect are present in 7 cases within this sub-sample and 41 cases overall. Prominent too within the reviewed cases are scenarios where alcohol and/or drug abuse are accompanied by financial and physical abuse by third parties.

\begin{tabular}{|c|c|c|c|c|}
\hline Case number & SAB, date, case & Gender, age & Living situation & Circumstances \\
\hline 101 & $\begin{array}{l}\text { Rochdale, 2017, } \\
\text { Tom }\end{array}$ & Male, 61 & Lived alone & Murdered \\
\hline 102 & $\begin{array}{l}\text { Brighton \& Hove, } \\
2017, X\end{array}$ & Transgender, 59 & Homeless & Died \\
\hline 103 & $\begin{array}{l}\text { Council I, 2016, } \\
\text { Mr K }\end{array}$ & Male, 62 & $\begin{array}{l}\begin{array}{l}\text { Lived with wife \& } \\
\text { children }\end{array} \\
\end{array}$ & Died in hospital \\
\hline 104 & $\begin{array}{l}\text { Richmond, 2017, } \\
\text { Mr T }\end{array}$ & $\begin{array}{l}\text { Male, no age } \\
\text { given }\end{array}$ & Lived alone & Died in fire \\
\hline 105 & $\begin{array}{l}\text { Council J, 2016, } \\
\text { Mr A }\end{array}$ & $\begin{array}{l}\text { Male, no age } \\
\text { given }\end{array}$ & Lived alone & Died in care home \\
\hline 106 & $\begin{array}{l}\text { Somerset, 2016, } \\
\text { Tom }\end{array}$ & Male, 43 & Lived alone & Took his own life \\
\hline 107 & $\begin{array}{l}\text { Council K, 2017, } \\
\text { KS }\end{array}$ & Male, 56 & \begin{tabular}{|l|} 
Temporary \\
accommodation
\end{tabular} & Died at home \\
\hline 108 & Devon, 2016, T & Female, 64 & Lived alone & Died \\
\hline 109 & $\begin{array}{l}\text { Somerset, 2016, } \\
\text { RR }\end{array}$ & Male, 33 & \begin{tabular}{|l|} 
Temporary \\
residential unit \\
\end{tabular} & Died by suicide \\
\hline 110 & $\begin{array}{l}\text { East Sussex, 2017, } \\
\text { Mr A }\end{array}$ & Male, 64 & Care home & Died \\
\hline 111 & $\begin{array}{l}\text { Havering, 2017, } \\
\text { Ms A }\end{array}$ & Female, 20 & Social housing & Died after jumping \\
\hline 112 & $\begin{array}{l}\text { Barking \& } \\
\text { Dagenham, 2017, } \\
\text { Mary }\end{array}$ & Female, 83 & Lived alone & Died at home \\
\hline 113 & $\begin{array}{l}\text { Barking \& } \\
\text { Dagenham, 2017, } \\
\text { Lawrence }\end{array}$ & Male, 63 & $\begin{array}{l}\text { Sheltered } \\
\text { accommodation }\end{array}$ & Died at home \\
\hline 114 & $\begin{array}{l}\text { Teeswide, 2017, } \\
\text { Carol }\end{array}$ & Female, 39 & Lived alone & Murdered \\
\hline 115 & $\begin{array}{l}\text { Gloucestershire, } \\
\text { 2017, Hannah }\end{array}$ & Female, 26 & Lived alone & $\begin{array}{l}\text { Died at home of } \\
\text { heart attack }\end{array}$ \\
\hline 116 & $\begin{array}{l}\text { Plymouth, 2017, } \\
\text { V }\end{array}$ & Male, 35 & Lived alone & Died \\
\hline 117 & $\begin{array}{l}\text { South Tyneside, } \\
2017 \text {, Adult D }\end{array}$ & Male, late fifties & Lived alone & Died in hospital \\
\hline
\end{tabular}




\begin{tabular}{|c|c|c|c|c|}
\hline 118 & $\begin{array}{l}\text { Nottinghamshire, } \\
\text { 2017, Adult H }\end{array}$ & Female, 20 & $\begin{array}{l}\text { Lived with family } \\
\text { members }\end{array}$ & Living at home \\
\hline 119 & $\begin{array}{l}\text { Bedford Borough } \\
\text { \& Central Beds, } \\
\text { undated, Ms A }\end{array}$ & Female, not given & $\begin{array}{l}\text { Lived with family } \\
\text { members }\end{array}$ & Left the UK \\
\hline 120 & $\begin{array}{l}\text { West Berkshire, } \\
2017, X\end{array}$ & Male, not given & Not specified & Died \\
\hline 121 & $\begin{array}{l}\text { Kent \& Medway, } \\
\text { 2017, Mrs D }\end{array}$ & Female, 68 & $\begin{array}{l}\text { Independent } \\
\text { living } \\
\text { accommodation }\end{array}$ & $\begin{array}{l}\text { Died in fire at } \\
\text { home }\end{array}$ \\
\hline 122 & $\begin{array}{l}\text { Worcestershire, } \\
2017, \text { RN }\end{array}$ & Male, 48 & Lived alone & Died \\
\hline 123 & $\begin{array}{l}\text { Worcestershire, } \\
\text { 2017, Neil }\end{array}$ & Male, 78 & $\begin{array}{l}\text { Lived alone, then } \\
\text { care home }\end{array}$ & $\begin{array}{l}\text { Died in a nursing } \\
\text { home }\end{array}$ \\
\hline 124 & $\begin{array}{l}\text { Nottingham City, } \\
\text { 2017, Adult C }\end{array}$ & Male, not given & Homeless & Unclear \\
\hline 125 & $\begin{array}{l}\text { Nottingham City, } \\
\text { 2016, Adult B }\end{array}$ & Male, 75 & $\begin{array}{l}\text { Living with his } \\
\text { wife }\end{array}$ & Died \\
\hline 126 & $\begin{array}{l}\text { Slough, 2015, Mrs } \\
\text { EE }\end{array}$ & Female, 93 & $\begin{array}{l}\text { Living with her } \\
\text { son }\end{array}$ & Died \\
\hline 127 & $\begin{array}{l}\text { West Sussex, } \\
\text { 2016, Alan }\end{array}$ & Male, 41 & Lived alone & Died from a fall \\
\hline 128 & $\begin{array}{l}\text { Waltham Forest, } \\
\text { 2017, Andrew }\end{array}$ & Male, not given & $\begin{array}{l}\text { Supported } \\
\text { housing }\end{array}$ & Died \\
\hline 129 & $\begin{array}{l}\text { Southwark, 2016, } \\
\text { Adult A }\end{array}$ & Male, 45 & Hostel & Died \\
\hline 130 & $\begin{array}{l}\text { Buckinghamshire, } \\
\text { 2017, Adult T }\end{array}$ & Female, not given & Lived alone & Died \\
\hline 131 & $\begin{array}{l}\text { Wandsworth, } \\
\text { 2017, WWF }\end{array}$ & Female, 88 & Lived alone & Died \\
\hline 132 & $\begin{array}{l}\text { Plymouth, 2017, } \\
\text { Ruth Mitchell }\end{array}$ & Female, 40 & Lived alone & Died \\
\hline 133 & Camden, 2017, YY & Male,58 & $\begin{array}{l}\text { Living with his } \\
\text { mother }\end{array}$ & Died \\
\hline 134 & $\begin{array}{l}\text { Buckinghamshire, } \\
\text { 2017, Adult Q }\end{array}$ & Male, 74 & Lived alone & Died \\
\hline
\end{tabular}

\section{Layer two: key characteristics of the SAR}

Within this sub-sample, self-neglect is usually the central focus rather than implicit or peripheral. Across the whole sample ( $n=134)$, where information is available, it is the central focus in $59 \%$ of cases, implicit in $24 \%$ and peripheral in $12 \%$. Once again, various methodologies have been employed, although in this sub-sample the traditional approach of independent management reviews, combined chronology and panel deliberation appears less common than a hybrid approach involving a systemic orientation that also uses learning events and/or interviews. This trend has also been noted in thematic reviews of completed SARs (Braye and Preston-Shoot, 2017; Preston-Shoot, 2017a). Within this sub-sample, most reviews (27/34) contain ten or fewer findings/recommendations, replicating a trend towards fewer priority actions noted elsewhere (Preston-Shoot, 2017a). 


\begin{tabular}{|c|c|c|c|c|}
\hline Case number & $\begin{array}{l}\text { Published, type, } \\
\text { length }\end{array}$ & Methodology & Self-neglect focus & Recommendations \\
\hline 101 & $\begin{array}{l}\text { Published, SAR, } \\
57 \text { pages }\end{array}$ & $\begin{array}{l}\text { IMRs, chronology } \\
\text { \& panel }\end{array}$ & Central & 9 \\
\hline 102 & $\begin{array}{l}\text { Published, SAR, } \\
32 \text { pages } \\
\end{array}$ & $\begin{array}{l}\text { IMRs \& } \\
\text { chronology }\end{array}$ & Central & 9 \\
\hline 103 & $\begin{array}{l}\text { Not published, } \\
\text { SAR, } 50 \text { pages } \\
\end{array}$ & SCIE & Central & 11 findings \\
\hline 104 & \begin{tabular}{|l|} 
Published, SAR \\
summary, 5 pages \\
\end{tabular} & SCIE & Central & $\begin{array}{l}3 \text { findings, } 6 \\
\text { recommendations }\end{array}$ \\
\hline 105 & $\begin{array}{l}\text { Not published, } \\
\text { SAR summary, } 3 \\
\text { pages }\end{array}$ & Learning review & Implicit & 3 \\
\hline 106 & \begin{tabular}{|l} 
Published, SAR, \\
31 pages \\
\end{tabular} & $\begin{array}{l}\text { IMRs, chronology } \\
\text { but not fully } \\
\text { specified }\end{array}$ & Central & 6 \\
\hline 107 & $\begin{array}{l}\text { Not published, } \\
\text { SAR, } 33 \text { pages }\end{array}$ & $\begin{array}{l}\text { Chronologies, } \\
\text { panel \& agency } \\
\text { enquiries }\end{array}$ & Implicit & 10 \\
\hline 108 & \begin{tabular}{|l|} 
Published, SAR \\
executive \\
summary, 7 pages
\end{tabular} & $\begin{array}{l}\text { Hybrid - } \\
\text { chronologies \& } \\
\text { interviews }\end{array}$ & Central & 6 \\
\hline 109 & $\begin{array}{l}\text { Published, SAR, } 9 \\
\text { pages }\end{array}$ & Meeting Sphere & Implicit & 10 \\
\hline 110 & $\begin{array}{l}\text { Published, SAR, } \\
54 \text { pages }\end{array}$ & $\begin{array}{l}\text { Hybrid - learning } \\
\text { event and } \\
\text { chronologies }\end{array}$ & Central & 23 \\
\hline 111 & $\begin{array}{l}\text { Published, SAR, } \\
52 \text { pages }\end{array}$ & $\begin{array}{l}\text { Hybrid - learning } \\
\text { events, reflective } \\
\text { questions and } \\
\text { chronologies }\end{array}$ & Central & 28 \\
\hline 112 & $\begin{array}{l}\text { Published, SAR, } \\
14 \text { pages }\end{array}$ & $\begin{array}{l}\text { Hybrid - learning } \\
\text { meeting, } \\
\text { chronologies }\end{array}$ & Central & $\begin{array}{l}3 \text { findings, } 6 \\
\text { recommendations }\end{array}$ \\
\hline 113 & \begin{tabular}{|l} 
Published, SAR, \\
44 Pages \\
\end{tabular} & SCIE & Central & 6 priority findings \\
\hline 114 & \begin{tabular}{|l} 
Published, SAR, \\
49 pages \\
\end{tabular} & SCIE & Central & 5 findings \\
\hline 115 & \begin{tabular}{|l} 
Published, SAR, \\
29 pages \\
\end{tabular} & Hybrid & Central & \\
\hline 116 & $\begin{array}{l}\text { Published, SCR, } \\
62 \text { pages } \\
\end{array}$ & $\begin{array}{l}\text { IMRs \& } \\
\text { chronologies }\end{array}$ & Central & 41 \\
\hline 117 & $\begin{array}{l}\text { Published, SAR, } \\
33 \text { pages }\end{array}$ & $\begin{array}{l}\text { Hybrid - learning } \\
\text { event, interviews, } \\
\text { chronologies }\end{array}$ & Central & 12 \\
\hline 118 & $\begin{array}{l}\text { Published } \\
\text { executive } \\
\text { summary, SAR, } 10 \\
\text { pages }\end{array}$ & SILP & Central & 6 \\
\hline
\end{tabular}




\begin{tabular}{|c|c|c|c|c|}
\hline 119 & $\begin{array}{l}\text { Published, } \\
\text { executive } \\
\text { summary, SAR, } 4 \\
\text { pages }\end{array}$ & $\begin{array}{l}\text { Hybrid - learning } \\
\text { event and } \\
\text { chronology }\end{array}$ & Peripheral & 10 \\
\hline 120 & $\begin{array}{l}\text { Published, case } \\
\text { summary }^{1}, 7 \\
\text { pages }\end{array}$ & $\begin{array}{l}\text { Summary of } \\
\text { learning from } \\
\text { other cases and } \\
\text { chronology }\end{array}$ & Central & 5 themes \\
\hline 121 & $\begin{array}{l}\text { Published, } \\
\text { executive } \\
\text { summary, SAR, } 12 \\
\text { pages }\end{array}$ & $\begin{array}{l}\text { IMRs \& } \\
\text { chronologies }\end{array}$ & Central & 6 \\
\hline 122 & $\begin{array}{l}\text { Published, SAR, } \\
41 \text { pages }\end{array}$ & $\begin{array}{l}\text { Hybrid - IMRs, } \\
\text { chronology \& } \\
\text { practice seminar }\end{array}$ & Central & $\begin{array}{l}2 \& \text { single agency } \\
\text { recommendations }\end{array}$ \\
\hline 123 & $\begin{array}{l}\text { Published, SAR, } \\
35 \text { pages }\end{array}$ & $\begin{array}{l}\text { IMRs \& } \\
\text { chronologies }\end{array}$ & Peripheral & 4 \\
\hline 124 & $\begin{array}{l}\text { Published } \\
\text { executive } \\
\text { summary, SAR, } 5 \\
\text { pages }\end{array}$ & $\begin{array}{l}\text { Hybrid - } \\
\text { chronology, } \\
\text { practice event \& } \\
\text { case appraisal }\end{array}$ & Implicit & $\begin{array}{l}5 \text { themes, } 3 \\
\text { recommendations }\end{array}$ \\
\hline 125 & $\begin{array}{l}\text { Published } \\
\text { executive } \\
\text { summary, SCR, } 15 \\
\text { pages }\end{array}$ & $\begin{array}{l}\text { Hybrid - } \\
\text { chronology, } \\
\text { meetings, } \\
\text { individual agency } \\
\text { appraisals, } \\
\text { learning event }\end{array}$ & Implicit & 9 \\
\hline 126 & $\begin{array}{l}\text { Published, } \\
\text { learning together } \\
\text { adult review, } 7 \\
\text { pages }\end{array}$ & SCIE & Implicit & 7 findings \\
\hline 127 & $\begin{array}{l}\text { Published, SAR, } \\
46 \text { pages }\end{array}$ & IMRs & Implicit & $\begin{array}{l}8 \text { \& individual } \\
\text { agency IMR } \\
\text { recommendations }\end{array}$ \\
\hline 128 & $\begin{array}{l}\text { Published, SAR, } \\
31 \text { pages }\end{array}$ & SCIE & Central & 4 findings \\
\hline 129 & $\begin{array}{l}\text { Published, SAR, } \\
39 \text { pages }\end{array}$ & $\begin{array}{l}\text { IMRs \& } \\
\text { chronologies }\end{array}$ & Implicit & 12 \\
\hline 130 & $\begin{array}{l}\text { Published, SAR, } \\
19 \text { pages }\end{array}$ & IMRs & Implicit & 8 \\
\hline 131 & $\begin{array}{l}\text { Published, SAR, } \\
39 \text { pages }\end{array}$ & SCIE & Central & 4 findings \\
\hline 132 & $\begin{array}{l}\text { Published, SAR, } \\
75 \text { pages }\end{array}$ & $\begin{array}{l}\text { Hybrid - IMRs, } \\
\text { chronologies, } \\
\text { learning event }\end{array}$ & Central & 12 \\
\hline 133 & $\begin{array}{l}\text { Published, SAR, } \\
60 \text { pages }\end{array}$ & $\begin{array}{l}\text { Hybrid - } \\
\text { chronology, } \\
\text { document review, }\end{array}$ & Central & 8 \\
\hline
\end{tabular}

\footnotetext{
${ }^{1}$ Although the case met the statutory criteria for a SAR, on grounds of proportionality, due to the learning already available locally and more widely from self-neglect cases, a summary of learning was constructed.
} 


\section{Layer Three: recommendations}

Within this sub-sample, recommendations are most commonly directed to a Safeguarding Adult Board (33 SARs) but Adult Social Care (6), Housing (5) and NHS Trusts (5) appear regularly. There are occasional recommendations for GPs, Pharmacists, Police, Ambulance Trusts, Public Health, Local Authority Commissioners and Clinical Commissioning Groups. Four reviews make recommendations to all the SAB's partner agencies. Increasingly recommendations are being directed to the $S A B$ alone (20 cases in the sub-sample), allocating to it the responsibility for ensuring an action plan is implemented, with policy and practice reflecting fully the review's conclusions. The specific involvement of other agencies as parties to the recommendations, such as Adult Social Care and the Police, is contained within this approach (case 112 is an example).

Some reviews reference recommendations offered by agencies as part of IMRs and/or reflective interviews. Cases 116, 117, 121, 130, 132 are examples where the precise nature of the recommendations is not specified, arguably undermining the quality marker of transparency. Cases $111,123,125$ and 127 offer examples where agency nominated recommendations are explicitly listed. Some evidence emerges of SABs requesting a limited number of SMART recommendations, locally focused (case 115 is an example). Occasionally reviews identify changes already implemented (case 116 is one instance), perhaps conscious of Wood's challenge (2016) that little is being learned from cases.

Across the entire sample ( $n=134), 74 \%$ of SARs make recommendations to a SAB and $42 \%$ to Adult Social Care. NHS Trusts receive recommendations in $26 \%$ of cases, Clinical Commissioning Groups in $23 \%$, Housing in $18 \%$, GPs in $14 \%$ and the Police in $10 \%$. Occasionally, other uniform services, care agencies, third sector agencies and children's services are named, reflecting again that safeguarding is everyone's business.

There remain reviews where recommendations do not specify the agencies towards which they are directed (6 in this sub-sample). As previously observed (Braye et al., 2015a), this potentially complicates the construction of action plans and the subsequent evaluation of the impact of learning.

\section{Layer Four: themes within recommendations}

Four broad categories of recommendations are retained - staff support, review process, best practice and procedures (Braye et al., 2015a). Within the sub-sample, 17 reviews recommend training and 7 improvements to supervision and support. Across the full sample, 59\% of reviews contain recommendations regarding training and $34 \%$ supervision, including access to specialist advice. Considerable faith is placed in training without explicit attention to workplace development 
alongside workforce development (Braye et al, 2013), to ensuring that staff can embed in practice what they have learned.

This sub-sample contains fewer concerns about how the review process unfolded and was managed; 3 SARs contain recommendations here, designed for example to improve the adequacy of IMRs and the management of serious incident investigations. Of greater concern appears the importance of learning from reviews, with 12 recommendations about dissemination locally and nationally. Although it now appears expected that SABs will construct action plans once a SAR has been accepted, eight reviews contain specific recommendations regarding the content and subsequent use to be made of them. Across the whole sample, $22 \%$ of reviews contain recommendations regarding action planning, $21 \%$ about future management of the review process and $30 \%$ about using the report for learning and service development.

Within the best practice theme in this sub-sample, mental capacity assessments drew 11 recommendations, including the importance of exploring people's choices, unravelling the notion of lifestyle choice and identifying desired outcomes from risk assessments. There were recommendations about person-centred, relationship-based approaches, and about different ways of seeking to engage with people who are refusing services in 16 reviews. Three SARs contained recommendations concerning knowledge and use of the law, and 7 on assessment and involvement of family carers. Across the entire sample, best practice in mental capacity assessments dominates the picture; $39 \%$ of reviews contain recommendations here. Mindful of the challenges of working with adults who self-neglect, $29 \%$ of reviews contain recommendations concerning engagement and $28 \%$ remind practitioners and managers of the importance of relationship-centred practice. The relationship focus extends to family members; $22 \%$ of reviews highlight assessment of carers and understanding family dynamics. $16 \%$ of SARs contain recommendations about legal literacy.

Recommendations continue to place faith in procedures. Within the sub-sample, 24 SARs recommend the development and/or review of guidance, for example on escalation of concerns and information-sharing as well as self-neglect itself. 12 focus on referral and assessment and 26 on case management, including the use of section 42 enquiries, safeguarding or self-neglect pathways, and reviews. Recommendations regarding working together occur in 25 cases, information-sharing in 17. Eleven cases refer to the importance of recording. Across the whole sample $(n=134), 71 \%$ of SARs recommend the development and/or review of guidance for staff; $62 \%$ focus on referral and assessment pathways. 58\% make recommendations regarding inter-agency working, whilst $56 \%$ focus also on case management (including care planning, reviews, quality audits and escalation of concerns). Recommendations regarding recording occur in $40 \%$ of cases, information-sharing in $43 \%$.

\section{Cross-case analysis}

Four domains now explore the themes emerging from this sample of reviews.

Domain A: practice with the individual adult

As evidenced previously (Preston-Shoot, 2016; 2017b), the importance of considering and responding to repeating patterns is highlighted $(106,111,127)$. Two cases $(120,121)$ observe that 
each referral episode was viewed in isolation rather than in the context of foregoing history. Reviews also continue to advise a "think family" approach, with liaison with children's services when indicated $(103,114)$. Family members (and neighbours) may hold information that might help practitioners to appreciate what is causing or maintaining self-neglectful behaviour, including a reluctance to accept help $(101,105,106,111,112,121)$. Practitioners need to engage with family members who provide support, especially when they are requesting help $(109,115,116,123)$. Equally, however, there may be complex co-dependent dynamics between caregivers and those they are caring for, perhaps involving abuse and neglect $(120,125,126,133)$. Carers assessments should be offered and be thorough, exploring mixed messages about giving care and support, willingness and ability to cope, and any evidence of difficulties and neglect $(103,106,109,125,134)$. However, practitioners must speak with the adult who self-neglects as the (hostile) presence of another person can affect their engagement $(117,118,124,127)$.

Tension between autonomy and duty of care remains a prominent theme, with multi-agency meetings seen as crucial to discuss differences of opinion between professionals, evaluate options and avoid defensive practice $(108,113,115,122,128,130-132,134)$. Several cases emphasise the importance of persistent offers of support, respectful challenge and updated risk assessments (102$104,109,120,129)$. Links are made here with exploring executive capacity $(105,106,114)$ as individual agency and choice may be more compromised than practitioners appreciate.

Criticisms continue of mental capacity assessments. Cases $(101,107,110,115,129)$ criticised practitioners for failing to record for which decisions the individual was assessed as having capacity and/or to consider the impact of impairment of executive brain function. Elsewhere capacity was assumed $(106,108,111,117,120-122,127,129,132)$. Sometimes assessment was insufficiently robust, perhaps because practitioners lack confidence in their knowledge and skills, and in taking best interest decisions $(113,125,133,134)$. Assessment must be contextual, cognisant of relationships surrounding the individual $(103,124)$ and include triangulation with known information, for example a person's mental health history $(103,114,120)$. The failure to involve advocates also emerges $(106,110,120,127,129)$.

On non-engagement, a key message is to express concerned curiosity about possible explanations. Simply sending letters, expecting individuals to respond positively to clinic/office appointments, and closing the case when no response has been received is insufficient $(103,106,111,114,116-118)$. Using different strategies to engage following missed appointments and monitoring cases through documented multi-agency meetings or "at risk pathways" are advised $(103,117,120,122,126,127$, 129).

A person-centred, relationship-based approach is emphasised to establish trust, appreciate the reasons behind self-neglect, explore perspectives and preferred options, offer support and wherever possible negotiate interventions $(101,106,116,129,131,132)$. A person-centred approach should not exclude expression of concerned curiosity or inquisitorial questioning $(107,118,134)$. It does not mean avoiding difficult conversations, including respectful challenge of decisions (128). Working with individuals should be characterised by empathy, respect and attention to the person's dignity (115), paying due regard also to their history $(102,103,109,117)$. 
SARs also focus on the lack of (robust and holistic) risk assessments $(101,102,105,106,112,116$, $121,125,130,132)$, including fire risk with smokers from the use of emollient creams (131) and suicidal ideation (109). Risks should be considered individually and collectively, culminating with thorough management plans $(106,127)$. SARs also emphasise the importance of a multi-agency approach that includes discussion of how self-neglect is viewed and routine updating in order to integrate responses to relapse indicators or welfare concerns $(106,111,114,117,122,129)$. Assessments should also be evidence-based, drawing on all available information rather than relying solely on a person's self-report $(103,122,124,129)$. Risks to other people should not be underestimated (120). Assessments should be broadly rather than narrowly configured, not just concentrating on presenting problems or on what is visible and practical $(125,134)$. All legal options should be considered to support risk management plans (104). SARs focus too on missed opportunities to conduct mental health assessments $(102,109,110,121,128,130)$. Referrers must be clear whether they are requesting a mental health or a Mental Health Act assessment $(110,133$, 134).

Subsequent planning should build on completed assessments. However, care plans do not always meet professional standards in terms of specificity and outcome-orientation $(114,116,125)$, nor are they always followed through (121). Other agencies may not be consulted $(109,113,121,122)$. Multi-agency planning is especially important at points of transition, with information-sharing, time, flexible working and use of specialist expertise all possibly indicated $(109,111,118,123)$.

Nonetheless, SARs also report good practice, such as evidence of making safeguarding personal (112, $123,128,131)$ and positive engagement that demonstrated consistent support, compassion and concern $(104,108,111,113,114,117,118,121,125)$. Quality reviews are noted of mental capacity assessments, risk assessments and care plans $(101,115,123)$.

\section{Domain B: the professional team around the adult}

Across health and social care, housing and uniform services there are examples of good practice raising safeguarding concerns, information-sharing, diligence and persistence in engaging with individuals, thorough discharge planning and follow-up, and working together $(101,104,108,109$, $114,115,117,118,120,125,129,130,131,134)$.

However, familiar criticisms continue of silo working, rigid eligibility thresholds and inflexible agency responses, which negatively impact on the support offered and leave people in harm's way (102, $106,120,121,128)$. People are referred on, or back and forth, with individuals with dual diagnosis particularly vulnerable to revolving agency doors $(102,128)$ rather than perspectives shared to inform integrated risk assessments and management plans. Awareness is lacking of what different agencies are already offering in a case or can contribute to safeguarding $(108,117,123,126,128$, $131)$, with assessments completed in isolation $(111,116)$ and adopting a narrow focus $(131)$.

Approaches are uncoordinated and disjointed $(110,111,114,121,132,133)$, with services failing to communicate, deliver timely provision and/or clarify their respective roles and responsibilities (105, $108,109,112,116)$. The absence of strategy meetings meant that there was no overall analysis of known information and no shared, agreed approach to assessment, case management and 
contingency planning $(112,116,125,127,131,133,134)$. Hospital discharge is a pivotal moment when multi-agency coordination is essential, including information-sharing, risk and mental capacity assessments, accurately identifying the community GP, notifying agencies involved and recommencing community health and social care services $(107,109,112,113,121,125,128,129$, $130,133)$.

A clear message emerges of the importance of multi-agency meetings, to support reflection and shared decision-making (104), with one agency or practitioner having a lead co-ordinating role to develop and oversee case management planning $(102,105,106,107,108,115,120,122,124,125$, 130). Multi-agency meetings are highlighted as particularly beneficial when a case has yet to reach the safeguarding threshold but where there are concerns about how agencies are working together to understand and manage risks $(120,128)$.

Even when held, multi-agency meetings would benefit from being more structured to improve coordination, continuity and communication between services $(101,126)$, for example when transferring cases between individuals or teams and when individuals are moving between settings, such as hospitals and home, and need services to restart $(108,113,122)$. When key professionals and agencies are absent from meetings, arrangements must be made to ensure they contribute to the on-going plans $(110,117)$.

Effective working together depends on information-sharing between community and secondary healthcare settings, District Nurses and GPs, children's and adult social care, Police and mental health providers. However, this was frequently found to be poor, resulting in no shared understanding of risks, for example arising from non-engagement or mental distress, or agreed multi-agency approach, and culminating in missed assessment opportunities and disjointed or delayed service provision $(103,107,108,111,112,116,117,120,121,122,125,127,129,130,132$, 134). Three reviews $(102,110,134)$ also highlight the importance of communication and a multiagency approach when individuals are placed across county boundaries.

Three reviews highlight the risks to multi-agency case management when a hierarchy of professional or agency voices exist $(111,128,131)$. When practitioners with particular knowledge of the case are not invited to meetings, or their concerns minimised, opportunities for information-sharing and joint risk assessment and care planning are lost.

Legal literacy is highlighted $(114,132)$ with staff requiring a better understanding of all legal options. Variable knowledge of mental capacity and mental health legislation is specifically highlighted (110, $111,133)$. Other reviews concluded that there were failures to seek legal advice (133), to appreciate when the right to private and family life can be qualified in order to share information $(116,128)$, to undertake care and support assessments (Care Act 2014, section 9) $(115,130)$, and to obtain injunctions to protect a person from abuse $(114,127)$. In case 129 the individual was not seen despite statutory obligations on agencies to remain in contact. In case 104 local authority funding was not explored when the individual refused to pay for services.

Safeguarding literacy emerges $(102,111,114,116,121,123,127,128,130,133,134)$ through concerns about the poor management and investigation of alerts, the failure to follow approved 
procedures, delays in raising or following up concerns, and poor communication about levels of risk. Sometimes adult at risk management procedures were poorly understood (120); sometimes safeguarding referrals were simply passed on to an agency known to be involved $(111,114)$; sometimes thresholds were misunderstood and/or misapplied or referral information was not triangulated with other available information before decision-making on whether to proceed with a safeguarding enquiry $(106,107,108,114,116,125,127)$. Occasionally, children's services staff and police officers were criticised for not understanding adult safeguarding law and procedures (103, 117).

One feature of safeguarding specifically highlighted is escalation, with available procedures not used $(108,114,123)$, or unclear and ineffective $(105,118,126,127)$. Sometimes concerns were not escalated $(107,116,120,122,125,131)$. Effective safeguarding depends on agencies challenging each other's decisions when concerns remain in order that alternative options are explored.

Some reviews are critical of recording standards $(101,106,108,114,115,116,117,121,122,129$, $131,132)$, for example of mental capacity and risk assessments, safeguarding concerns, medication and appointment management, referrals, care plans and decision-making rationale. Sometimes the criticism was of dispersed records or out of date information $(107,112)$ and of delay in transferring information, for example between GPs, with the result that newly involved practitioners were unsighted on case history and concerns $(110,111,123)$. Sometimes criticism is directed at IT systems that construct barriers to information-sharing and/or do not flag risks $(116,117,125)$.

\section{Domain C: organisations around the professional team}

One theme is commissioning for complex cases $(109,111,113,114,120,128,129)$, both residential and community, often involving mental health, addictions and/or non-compliant or chaotic behaviour. One review (115) explores the interface between commissioners and providers; another (108) observes that care home providers were not seen as part of the wider system responsible for ensuring personalised care. One review (117), in a context of market gaps, criticises domiciliary care agencies for taking contracts without the necessary capacity to deliver the requirements.

Glimpses are afforded into practitioners' working contexts. Cases $(103,114,120,130,131)$ refer to the impact of organisational change; others $(103,110,114,116,117,123,131)$ to the impact of staffing issues - vacancies, workloads, availability of advocates or specialist practitioners. Five cases refer to the impact of austerity on availability of care packages, care pathways and/or placements or services to address complex and challenging needs $(105,114,117,129,132)$.

Supervision, training, and senior management oversight remain constant themes $(104,105,107$, $111,116,117,120,121,125,127,128,129,130,133,134)$. Poor practice is not corrected, risks are not discussed, practitioners have insufficient knowledge and/or skills for the complexities that they encounter, including cultural awareness and identification of mental distress, and understanding of safeguarding procedures is lacking. Robust review and oversight are sometimes absent, with patchy performance monitoring and inadequate responses when staff raise concerns about feeling anxious or powerless in relation to risks of foreseeable harm. Support should be offered to enable staff to manage complex cases (114), including the availability of mental health, mental capacity and law 
specialists so that all options are considered. Staff must be able to put knowledge and skills acquired in training into practice, reiterating the importance of workplace as well as workforce development (Braye et al., 2013).

Evidence continues to suggest that available procedures are not used, for instance for convening multi-agency meetings regarding adults at risk of harm $(102,103,116,131)$. One review $(127)$ suggests that in a particular working environment there were too many policies for police officers to read and know. Yet faith in procedures remains prominent, with SARs $(103,111,116,130)$ recommending policies for self-neglect, missing persons, suicide risk and escalation. Unusually, given that reviews often eschew comment on the wider legal and policy system beneath which sit local adult safeguarding arrangements (Preston-Shoot, 2016), three SARs critique national guidance regarding non-disclosure of convictions of "informal carers" to an adult at risk (101), non-notification of an individual's move to another local authority area when a safeguarding alert has not been concluded (102), and lack of clarity about when self-neglect falls within section 42 (Care Act 2014) and safeguarding, particularly when people with capacity display very challenging risk-taking behaviour (128).

Nonetheless, there are references to good practice, for example supporting staff through grief and loss (128), diligent searches for specialist placements (114) and flexible commissioning to achieve person-centred outcomes despite financial pressures (131).

\section{Domain D: SABs and inter-agency governance}

Once again, in this sample this domain features less prominently. However, in line with statutory guidance ( $\mathrm{DH}, 2017)$ reviews comment on family involvement, frequently referring to the value this has added to the process, for example when setting terms of reference or understanding key events in a chronology. What might facilitate such involvement is left unexplored. Otherwise, in terms of the process of conducting SARs, there are references to delays owing to parallel processes ${ }^{2}$, finding independent reviewers (133) and obtaining quality contributions from some agencies (134). Other reviews observe that time constraints can limit the depth of investigation $(113,115)$, that inconsistent panel membership impacts on developing understanding of the review process (103), and that the passage of time between case events and the review itself results in loss of records and/or availability of staff involved at the time (132) and elevates the risk of hindsight bias.

More positively, some reviews mention participants' candour, their willingness to engage in reflection, and effective management of the review process itself, including the availability of staff with specialist knowledge to act as advisors $(103,111,114,115,122)$.

Emphasis continues to be placed on the use of SARs, so that lessons may be learned, but limited use is made of other reviews completed by the commissioning SAB and/or nationally ${ }^{3}$. Case 120 represents an interesting development, however, where the SAB determined that a proportionate response would be to research learning available locally and nationally from other SARs, with links

\footnotetext{
${ }^{2}$ Examples include police investigations and criminal proceedings, inquests and inquiries by regulatory or professional bodies $(122,127,132,133)$.

${ }^{3}$ Cases 120 and 134 by contrast do make use of other completed reviews.
} 
made across to the referred case. This SAB's judgement was that this would be more likely to produce new learning.

SARs also pay attention to single agency action plans (for example 117, 118, 122, 123, 125, 134) and occasionally point to changes that have already been implemented. What is impossible to determine from the SARs, of course, is the lasting impact on system-wide change.

\section{Demonstrating change}

This analysis of SARs on self-neglect prompts two immediate observations. Firstly, significant learning can emerge when individual cases are reviewed, as captured in findings and recommendations. Secondly, thematic overviews across a sample produce a comparative and more nuanced perspective of the complexities involved in working with adults who self-neglect. However, a third observation also arises, namely that completion of a SAR opens another chapter, namely the transfer of learning into policy and practice, locally and beyond.

There has been little evaluative inquiry about whether learning from SARs directly impacts on policy and practice and little theorising about how to manage this challenge of effecting change within and across adult safeguarding systems. Stanley and Manthorpe (2004), surveying different kinds of inquiry, found mixed evidence of their effectiveness in changing systems and practices. Along with others who have conducted thematic analysis of reviews (Brandon et al., 2005) they questioned whether there was sufficient energy left after report publication for translating its recommendations into action for change.

The critique partly revolves around failure to disseminate and learn lessons locally, and to transfer them into wider policy and practice (Fyson et al., 2004; Cambridge, 2004; Devaney et al., 2011). Another aspect emphasises the difficulty of translating case-based findings to learning across practice (King, 2003; Horwath and Tidbury, 2009). Thematic reviews of SCRs have concluded that a stronger emphasis is required on creating robust learning cultures through which learning can be translated into action (OFSTED, 2008; Rose and Barnes, 2008; Devaney et al., 2011). One study of barriers and enablers to learning from reviews (Rawlings et al., 2014), at the practitioner level, focuses on workloads, support to manage the emotional aspects of casework, training and supervision to develop knowledge and skills, and staff involvement in generating the learning to be implemented. At a service level, the study focuses on acknowledging that change takes time and sustained leadership, making reports and the learning from them accessible and relevant, and creating a learning culture within and across agencies, with a continued programme to reinforce desired changes. It acknowledges that too many recommendations and changes can prove unsettling and create confusion in people's roles and responsibilities. It advises the use of audits to monitor the impact of change.

Although its conclusions have been contested (Preston-Shoot, 2017b), the challenge of change was crystallised by the Wood Review (2016), which argued that SCRs had produced little effective change as evidenced by their repetitive findings. SABs must be able to answer the question of how they know that SARs have beneficially impacted on procedures and practice, at least locally. Thematic reviews have uncovered some positive findings regarding impact. Braye and Preston-Shoot (2017) 
found that review findings had already been used in service development. Action plans too were very specific, with an emphasis on subsequent audit and quality assurance. Preston-Shoot (2017a) also found that reviews had had an immediate impact on service development within individual agencies and/or across the multi-agency safeguarding partnership. Recommendations and action plans were generally focused, the latter updated with progress made. Some SABs had developed focused approaches to dissemination, involving briefings, the development of training materials, and conference presentations. Less prominent, however, were audits to explore the degree to which direct practice with adults at risk, and the supporting organisational and multi-agency context, reflected the desired changes.

Central government's own experience of implementing recommendations from a review is illuminating and instructive. The Department of Health's report (2015) on progress in transforming care following the Winterbourne View SCR (Flynn, 2012) admits that change has taken longer than planned. Even with a step-change in leadership, achieving legislative and regulatory change has proved easier than addressing a fragmented commissioning landscape, the breadth and depth of provision required for people with complex needs, complicated funding systems and the availability of sufficiently skilled staff to ensure that service users receive the right support.

So, how might change be approached and achieved? The question to be answered (Rose and Barnes, 2008) is "how to create sustainable change?"

\section{Approaching change}

In conceptualising an approach to implementing SAR recommendations, components have been drawn from research on leading change (Kotter, 1995) and on utilisation of research (Walter et al., 2004), besides reflections on the review process itself (for example, Fish et al., 2009; Horwath and Tidbury, 2009; Devaney et al., 2011). Although presented sequentially for clarity, the framework for approaching change is not so much a step-by-step model as a set of interlocking elements, all of which should always be kept in mind. 
Participating in SARs impacts on staff involved and on relationships within and between agencies (King, 2003; Horwath and Tidbury, 2009). Some debriefing with practitioners and managers may be necessary and some rebuilding of collaborative arrangements to lay the groundwork for the desired changes. Momentum, what Kotter (1995) describes as a sense of urgency, is necessary to generate co-operation that ensures that the SAR will have an impact on policy and practice. Leadership is necessary here and throughout, with the Board providing a powerful guiding presence (Kotter, 1995). The Board's acceptance of the SAR's analysis and its implications is obviously important but the $S A B$ also needs to have sufficient senior management engagement to drive the change process, supported by middle and practice managers, staff development personnel, commissioners and regulatory bodies (Walter et al., 2004). A review, therefore, of aspects of its governance may be necessary.

Action plans should be specific about what needs to change and how that outcome would be identified (Rose and Barnes, 2008). However, action planning can become formulaic without articulating a vision (Kotter, 1995) for what good policy and practice looks like, as when working with cases of self-neglect. As Cambridge (2004) concluded, the desired state should be mapped, followed by the individual and organisational responses required to achieve it. SAR authors can assist here by building up a model for effective practice, here on self-neglect, by collating learning from individual and thematic reviews. Terms of reference for individual SARs, and quality standards for reviews (SCIE and NSPCC, 2016; London ADASS, 2017), should therefore include the degree to which already available learning is applied to the case in question and the recommendations emerging from it.

This is one point where a sustained relationship with SAR authors may be advantageous, assisting the $S A B$ to develop and then implement its action plan. 


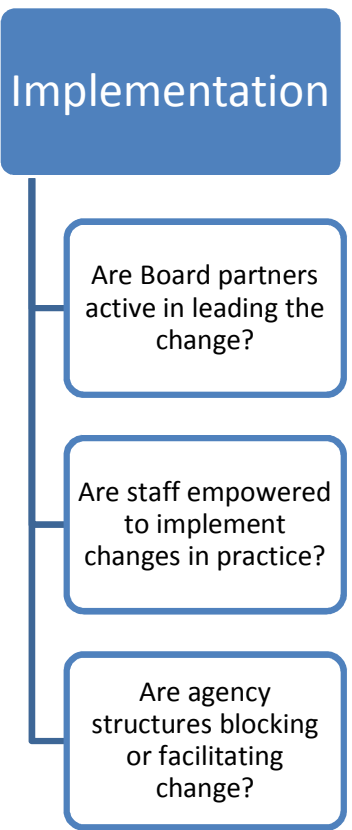

Dissemination is one challenge. Simply publishing and/or circulating the whole report, or an executive summary, is too passive. To promote adaptation to change, the vision of what good looks like and its necessary component parts needs to be communicated to diverse management and practitioner audiences. Materials for doing so should be tailored explicitly for specific audiences. They include briefings and training materials, accessible and actively disseminated, with the implications for different staff and agencies clearly articulated (Walter et al., 2004). Expectations should be clearly stated about how they will be used actively by the teams to which they are sent, together with feedback sheets that team members complete to indicate how and when they have been understood and used.

Implementation is another challenge. It requires a whole system approach. It is not just a case of devising a new procedure or advocating a different orientation to practice. SARs take place "somewhere" and, whether or not all features of that place are acknowledged in the review, implementation of change as reflected in the recommendations will need to take account of the national and local social, political, economic, legal, regulatory and professional contexts.

Favourable political, organisational, inter-agency and staffing conditions must be created for change to occur; otherwise familiar barriers of staff turnover, resource constraint and workloads will frustrate the vision that underpins new procedures and/or desired practices (Cambridge, 2004; Rose and Barnes, 2008; Fish et al., 2009). A supportive political policy climate can ease adoption of new procedures and practices, recognising that some recommendations will require national action. Organisational structures and institutional cultures may have to be changed to allow desired practice to flourish - an alignment between workplace cultures and policies, agency procedures and practice (Walter et al., 2004; Braye et al., 2013; Pike and Wilkinson, 2013). Staff themselves should feel that they have the authority, as well as the training and resources, to deliver the vision being articulated in the review recommendations and subsequent action plan. Obstacles to change have to be identified and removed, what Kotter (1995) describes as enabling actions, with staff empowered to 
act in line with the articulated vision of best practice. In working with adults who self-neglect, for example, that means staff being encouraged to build and maintain relationships, to provide continuity of concern and care.

No one service can deliver effective adult safeguarding alone so attention may be necessary on the health of inter-agency strategic and operational relationships. Working conditions experienced by staff can support adoption of change or create an unsafe environment. The focus here falls on what people bring to their work and the context in which they practise - their knowledge and skill mix, the optimism or pessimism with which they approach change, and their resilience and capacity for reflection; manageable workloads, supervision and the availability of spaces for reflection.

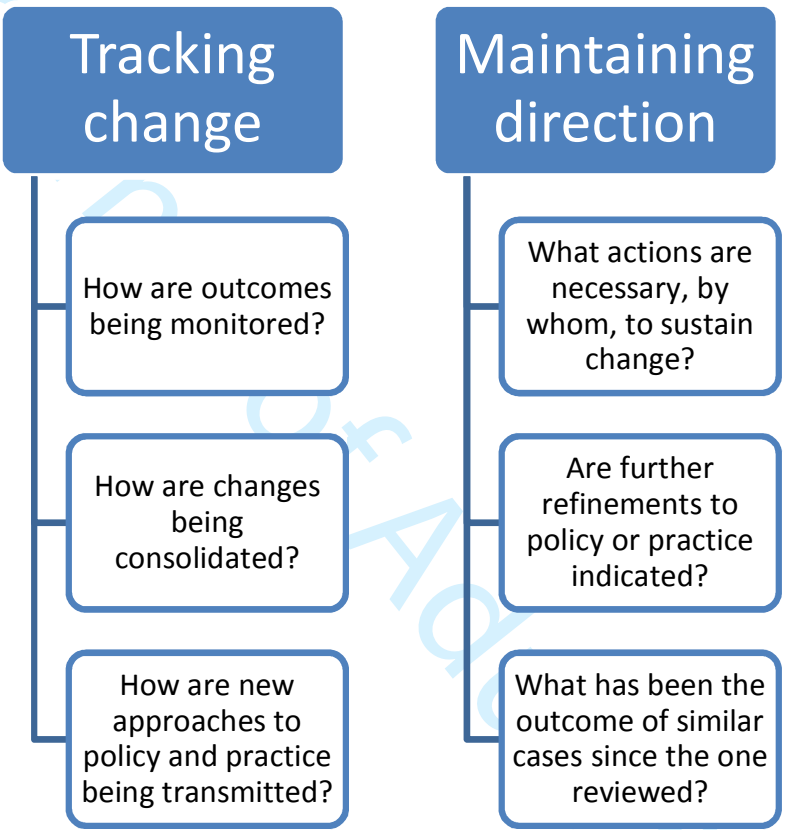

Once again, the Board needs to be providing leadership, the powerful guiding presence (Kotter, 1995). Here, however, the focus is on using supervision, case audits and seminars to maintain a focus on embedding implementation (Walter et al., 2004) - to reflect back on what has changed (Rose and Barnes, 2008) and to assess current single and multi-agency strengths and vulnerabilities when working with the type of case in question when compared with what good looks like as identified by SARs and other research. One example (Rochdale SAB, 2017) is a multi-agency case file audit on self-neglect that lists known elements of good practice and then captures the issues uncovered, messages for practitioners and multi-agency recommendations.

It is tempting to conclude that the action plan has been completed when policies have been developed or revised, training offered, and assurances received about practice and supervision. Closing down the action plan at that point, however, neglects consolidation and reinforcement of change. This is another juncture at which involvement of SAR authors might prove helpful in facilitating reflection on the journey travelled and the work still to be done to embed change.

\section{Conclusion}


The statutory guidance $(\mathrm{DH}, 2017)$ advises that SABs may commission reviews of cases where work has been effective in preventing abuse and neglect or protecting adults from significant harm. Learning will emerge from reviews where practice has been effective, acting as a counterpoint to the messages from SARs. Statistics demonstrate that adult safeguarding is effective (NHS Digital, 2016) but the degree to which SABs are reviewing, auditing and disseminating successful practice is unclear.

Thematic reviews unify learning that otherwise remains localised and disparate. They therefore contribute to developing patterns of understanding and knowledge through the syntheses and generalisations, contrasts and comparisons that can be drawn. They provide one means of enabling SABs, individually and collectively, to scale up the impact of completed SARs.

Translating findings and recommendations into policy and practice is not straightforward. The argument in the second half of this article is that SABs should act not just on the recommendations but on the different levels of context where change may be necessary to realise the ambitions reflected in the SAR's conclusions. A longitudinal approach is needed to embed and then demonstrate the ultimate value of SARs, one that reaches beyond the completion of an immediate action plan to on-going evidence of practice and organisational change. It requires leadership and conversations that attend to cultures, structures, processes, feelings and relationships; to understanding the meanings given to what is happening and why, and then to acting into those human and non-human contexts to achieve change.

\section{References}

Brandon, M., Dodsworth, J. and Rumball, D. (2005) 'Serious case reviews: learning to use expertise.' Child Abuse Review, 14, 160-176.

Braye, S. and Preston-Shoot, M. (2017) Learning from Safeguarding Adult Reviews: A Report for the London Safeguarding Adults Board. London: London Safeguarding Adults Board.

Braye, S., Orr, D. and Preston-Shoot, M. (2013) A Scoping Study of Workforce Development for SelfNeglect. Leeds: Skills for Care.

Braye, S., Orr, D. and Preston-Shoot, M. (2015a) 'Learning lessons about self-neglect? An analysis of serious case reviews.' Journal of Adult Protection, 17 (1), 3-18.

Braye, S., Orr, D. and Preston-Shoot, M. (2015b) 'Serious case review findings on the challenges of self-neglect: indicators for good practice.' Journal of Adult Protection, 17 (2), 75-87.

Cambridge, P. (2004) 'Abuse inquiries as learning tools for social care organisations.' In N. Stanley and J, Manthorpe (eds) The Age of Inquiry: Learning and Blaming in Health and Social Care. London: Routledge. Pages 231-254. 
Department of Health (2015) Winterbourne View: Transforming Care Two Years On. London: The Stationery Office.

Department of Health (2017) Care and Support Statutory Guidance: Issued under the Care Act 2014. London: The Stationery Office.

Devaney, J., Lazenbatt, A. and Bunting, L. (2011) 'Inquiring into non-accidental child deaths: reviewing the review process.' British Journal of Social Work, 41, 242-260.

Fish, S., Munro, E. and Bairstow, S. (2009) Learning Together to Safeguard Children: Developing a Multi-Agency Systems Approach for Case Reviews. London: Social Care Institute for Excellence.

Flynn, M. (2012) Winterbourne View Hospital: A Serious Case Review. Bristol: South Gloucestershire Safeguarding Adults Board.

Fyson, R., Kitson, D. and Corbett, A. (2004) 'Learning disability, abuse and inquiry.' In N. Stanley and J, Manthorpe (eds) The Age of Inquiry: Learning and Blaming in Health and Social Care. London: Routledge. Pages 215-230.

Horwath, J. and Tidbury, W. (2009) 'Training the workforce following a serious case review: lessons learnt from a death by fabricated and induced illness.' Child Abuse Review, 18, 181-194.

King, S. (2003) 'Managing the aftermath of serious case reviews.' Child Abuse Review, 12, 261-269.

Kotter, J. (1995) 'Leading change: why transformation efforts fail.' Harvard Business Review, MarchApril, 59-67.

London ADASS (2017) Safeguarding Adult Reviews (SARs) Quality Markers: Supporting Dialogue about the Principles of Good Practice. Unpublished draft for London SAB.

NHS Digital (2016) Safeguarding Adults Annual Report, England. 2015-16 Experimental Statistics. www.digital,nhs.uk

OFSTED (2008) Learning Lessons, Taking Action: OFSTED's Evaluations of Serious Case Reviews 1 April 2007 to 31 March 2008. Manchester: OFSTED.

Pike, L. and Wilkinson, K. (2013) How to Get Learning into Practice. Dartington: RiPfA.

Preston-Shoot, M. (2016) 'Towards explanations for the findings of serious case reviews: understanding what happens in self-neglect work.' Journal of Adult Protection, 18 (3), 131-148.

Preston-Shoot, M. (2017a) What Difference Does Legislation Make? Adult safeguarding through the Lens of Serious Case Reviews and Safeguarding Adult Reviews. A Report for South West Region Safeguarding Adults Boards. Bristol: South West ADASS. 
Preston-Shoot, M. (2017b) 'On Self-Neglect and Safeguarding Adult Reviews: Diminishing Returns or Adding Value?' Journal of Adult Protection, 19 (2), 53-66.

Rawlings, R., Paliokosta, P., Maisey, D., Johnson, J., Capstick, J. and Jones, R. (2014) A Study to Investigate Barriers to Learning from Serious Case Reviews and Identify Ways to Overcome these Barriers. London: DfE.

Rochdale SAB (2017) Multi-Agency Case File Audit (Self-Neglect).

www.rsab.org.uk/professionals/safeguarding adult reviews and audits (accessed $17^{\text {th }}$ September).

Rose, W. and Barnes, J. (2008) Improving Safeguarding Practice. Study of Serious Case reviews 20012003. London: Department for Children, Schools and Families.

SCIE and NSPCC (2016) Serious Case Review Quality Markers. Supporting Dialogue about the Principles of Good Practice and How to Achieve Them. London: Social Care Institute for Excellence and National Society for the Prevention of Cruelty to Children.

Stanley, N. and Manthorpe, J. (2004) 'Introduction: the inquiry as Janus.' In N. Stanley and J, Manthorpe (eds) The Age of Inquiry: Learning and Blaming in Health and Social Care. London: Routledge. Pages 1-16.

Walter, I., Nutley, S., Percy-Smith, J., McNeish, D. and Frost, S. (2004) Improving the Use of research in Social Care Practice. London: SCIE.

Wood, A. (2016) Wood Report. Review of the Role and Functions of Local Safeguarding Children Boards. London: The Stationery Office. 